\title{
Sixty Years After the First Description: Genome Sequence and Biological Characterization of European Wheat Striate Mosaic Virus Infecting Cereal Crops
}

\author{
Merike Sõmera, ${ }^{1, \dagger}$ Anders Kvarnheden,,2,3 Cécile Desbiez, ${ }^{4}$ Dag-Ragnar Blystad, ${ }^{5}$ Pille Sooväli, ${ }^{6}$ Jiban Kumar Kundu, \\ Mark Gantsovski, ${ }^{1}$ Jim Nygren, ${ }^{2}$ Hervé Lecoq, ${ }^{4}$ Eric Verdin, ${ }^{4}$ Carl Spetz, ${ }^{5}$ Lucie Tamisier, ${ }^{8}$ Erkki Truve,${ }^{1}$ \\ and Sébastien Massart ${ }^{8}$ \\ ${ }^{1}$ Department of Chemistry and Biotechnology, Tallinn University of Technology, Akadeemia tee 15, Tallinn 10618, Estonia \\ 2 Department of Plant Biology, Swedish University of Agricultural Sciences, Almas allé 5, Uppsala 75651, Sweden \\ ${ }^{3}$ Institute of Agricultural and Environmental Sciences, Estonian University of Life Sciences, Kreutzwaldi 1, Tartu 51006, Estonia \\ ${ }^{4}$ INRA, UR407, Unité de Pathologie Végétale, Montfavet 84140, France \\ ${ }^{5}$ Division of Biotechnology and Plant Health, Norwegian Institute of Bioeconomy Research, Høgskolevegen 7, Ås 1433, Norway \\ ${ }^{6}$ Division of Plant Protection, Estonian Crop Research Institute, Aamisepa 1, Jõgeva 48309, Estonia \\ ${ }^{7}$ Division of Crop Protection and Plant Health, Crop Research Institute, Praha 16106, Czech Republic \\ ${ }^{8}$ Integrated and Urban Plant Pathology Laboratory, Gembloux Agro-Bio Tech (GxABT), University of Liège, Passage des Déportés 2, \\ Gembloux 5030, Belgium \\ Accepted for publication 16 October 2019.
}

\begin{abstract}
High-throughput sequencing technologies were used to identify plant viruses in cereal samples surveyed from 2012 to 2017. Fifteen genome sequences of a tenuivirus infecting wheat, oats, and spelt in Estonia, Norway, and Sweden were identified and characterized by their distances to other tenuivirus sequences. Like most tenuiviruses, the genome of this tenuivirus contains four genomic segments. The isolates found from different countries shared at least $92 \%$ nucleotide sequence identity at the genome level. The planthopper Javesella pellucida was identified as a vector of the virus. Laboratory transmission tests using this vector indicated that wheat, oats, barley, rye, and triticale, but none of the tested pasture grass species (Alopecurus pratensis, Dactylis glomerata, Festuca rubra, Lolium multiflorum, Phleum pratense, and Poa pratensis), are susceptible. Taking into account the vector and host range data, the tenuivirus we have found most probably represents European wheat striate mosaic virus first identified
\end{abstract}

ABSTRACT about 60 years ago. Interestingly, whereas we were not able to infect any of the tested cereal species mechanically, Nicotiana benthamiana was infected via mechanical inoculation in laboratory conditions, displaying symptoms of yellow spots and vein clearing evolving into necrosis, eventually leading to plant death. Surprisingly, one of the virus genome segments (RNA2) encoding both a putative host systemic movement enhancer protein and a putative vector transmission factor was not detected in $N$. benthamiana after several passages even though systemic infection was observed, raising fundamental questions about the role of this segment in the systemic spread in several hosts.

Keywords: cereal virus, European wheat striate mosaic virus, insect vector transmission, Javesella, oat striate and red disease, tenuivirus, virome, wheat striate mosaic, wheat virus, virology
The development of high-throughput sequencing (HTS) technologies has changed the paradigm of pathogen identification enabling untargeted detection of both known and unknown viruses that inhabit a particular organism or environment (Massart et al. 2014). When considering only the plant viruses, HTS has allowed the identification of hundreds of novel viral species from different genera and families and this number is growing fast (Villamor et al. 2019). Whereas the majority of these viruses are novel and data on the biology of these species is absent, some viral species have been biologically well characterized by scientists before the advent of molecular methods. Their host range, symptomatology and

${ }^{\dagger}$ Corresponding author: M. Sõmera; merike.somera@ttu.ee

Funding: Financial support was provided by Estonian Ministry of Education and Research Institutional research grant number IUT 19-3. Research visits of M. Sõmera to Swedish University of Agricultural Sciences were performed thanks to a Swedish Institute senior researcher scholarship, and M. Sõmera and E. Verdin to Gembloux Agro-BioTech were performed thanks to COST Action FA1407 (DIVAS) STSM grants. J. K. Kundu was supported by grant number MZe RO0418.

*The $\boldsymbol{e}$-Xtra logo stands for "electronic extra" and indicates that one supplementary figure and four supplementary tables are published online.

The author(s) declare no conflict of interest.

(C) 2020 The American Phytopathological Society transmission pathways have been studied without sequencing their genomes. Sequencing the genomes of these species is particularly useful as it will enable links to be made between novel molecular data and the existing scientific knowledge, and will accelerate collection of new data on their current distribution, economic and environmental impact. Moreover, it will also provide the first insights into their molecular biology and phylogeny.

In the present study, the use of HTS technologies led to sequencing and characterization of a virus genome most probably representing European wheat striate mosaic virus (EWSMV) that was studied in the 1950-60s. At that time, the attempts to purify virus particles did not succeed (Serjeant 1967) and the genome sequence of the virus remained unknown. Therefore, there are currently neither nucleic acid nor antibody detection assays available for this species. Partly because the planthopper vectors of EWSMVare difficult to keep alive under laboratory conditions (Kisimoto and Watson 1965), and also probably because the field impact of the disease seemed to be limited, the studies ended after the 1960s.

Wheat striate mosaic disease caused by EWSMV was suggested to be widespread in England already in 1956 and it was suspected to occur also in Spain, Denmark, and Germany (Slykuis and Watson 1958). At the same time, a disease with very similar biological characteristics was observed and studied in former Czechoslovakia (Průša and Vacke 1960a), Finland (Ikäheimio 1960), and Sweden (Lindsten 1961). These parallel studies revealed coincidences in host 
ranges and vector species as well as a similar symptomatology on infected plants of the possible disease agent from the different countries. Therefore, it was concluded that the same virus could be the causal agent of the disease in Northern and Central Europe (Brčak 1979; Lindsten 1979).

In field conditions, EWSMV was recorded to infect cereal crops (wheat Triticum aestivum, oats Avena sativa, barley Hordeum vulgare, and rye Secale cereale) and possibly some pasture grass species like perennial ryegrass (Lolium perenne), Italian ryegrass (L. multiflorum), annual meadowgrass (Poа аппиа), soft brome (Bromus hordeaceus), and timothy (Phleum pratense) (Slykuis and Watson 1958; Vacke and Průša 1961). However, the attempts to infect timothy under laboratory conditions failed (Ikäheimio 1964; Vacke and Prưša 1961), and the other mentioned grass species were infected at a low frequency in the laboratory (percentage of successful infections varied between $3.3 \%$ for L. perenne to $18.7 \%$ for B. hordeaceus) (Slykuis and Watson 1958; Vacke and Prǔša 1961). Experimental tests found at least 29 species of grasses to be susceptible to EWSMV (a majority of these species were the wild relatives of oat, wheat, and barley) but no dicotyledonous host species (Ikäheimio 1964).

On cereal crops, the initial symptoms - chlorotic striated spots on leaves and stalks - appeared 2 to 4 weeks after infection leading to the development of general chlorosis. In case of infected oats, the disease was sometimes described as "oat striate and red" because it was observed that plants may turn reddish yellow or red before they shrivel and die. Crop plants infected at seedling stage or before tillering were usually stunted and died within 1 or 2 months, whereas the infected grasses developed a chlorotic mosaic and became stunted (Ikäheimio 1960; Lindsten 1961; Slykuis and Watson 1958; Vacke and Průša 1961).

The disease was shown to be transmitted by polyphagous planthoppers belonging to the family Delphacidae and the genus Javesella (Fennah): J. pellucida (Slykuis and Watson 1958; Průša and Vacke 1960b), J. obscurella (Ikäheimio and Raatikainen 1961), and J. dubia (Kisimoto and Watson 1965). Vectors fed on symptomatic plants or injected with infectious extracts showed a latent period of 1 week to 1 month before they were able to transmit virus to new plants. Moreover, the studies on virus vectors showed that the virus can be transmitted transovarially from insect to insect through sperm of viruliferous males and by viruliferous female planthoppers to their eggs (Průša and Vacke 1960a; Slykuis and Watson 1958).

In England and Sweden, EWSMV was supposed to be a widely distributed, but economically not important pathogen, which infects weeds and insect vectors, and only occasionally is transmitted to cereal crops (Lindsten 1974; Slykuis and Watson 1958). However, a report from former Czechoslovakia indicated that EWSMV infection can cause major crop losses, particularly in mixed infections with oat sterile dwarf virus (OSDV) (Průša and Vacke 1960b), a fijivirus also known to be transmitted by the planthoppers J. pellucida and J. obscurella (Ikäheimio and Raatikainen 1961). Differently from EWSMV, transovarial transmission was not observed for OSDV in comparative transmission studies (Průša and Vacke 1960a). No mutual antagonism was detected between EWSMV and OSDV either in the body of the vector or in the host cereals; however, infection with one virus did not prevent infection with the other although the symptoms of one virus were sometimes dominated by the symptoms of the other in infected cereal hosts (Lindsten 1974; Průša and Vacke 1960a).

\section{MATERIALS AND METHODS}

Field-collected cereal and insect samples. In Estonia, leaf samples of cereal plants (wheat, barley, oat, rye, and triticale) showing leaf chlorotic mottle or stripes, yellowing, reddening, stunting or other symptom characteristic of possible viral infection were collected from 47 fields in 2012 to 2015 (Supplementary Table S1) and submitted for HTS analysis.

In Norway, leaf samples showing symptoms of yellow striate and severe stunting were harvested in 2014 and 2017 from wheat fields at Leirsund, County of Akershus $\left(60^{\circ} 00^{\prime} 0.0^{\prime \prime} \mathrm{N}, 11^{\circ} 05^{\prime} 60.0^{\prime \prime} \mathrm{E}\right)$. The samples harvested in 2014 tested negative for wheat streak mosaic virus, wheat dwarf virus, barley yellow dwarf virus, barley mild mosaic virus, barley yellow mosaic virus, barley stripe mosaic virus, wheat spindle streak mosaic virus, and soilborne cereal mosaic virus by PCR and enzyme-linked immunosorbent assay (ELISA). The samples of winter wheat cultivar Jantarka collected on 6 July 2017 from the same location were used as the inoculum in mechanical virus transmission tests to infect indicator plants grown in insect-proof greenhouse. Subsequently infected $N$. benthamiana were subjected to HTS analysis.

Planthoppers were collected using a sweep net from an oat field in Hedesunda, Municipality of Sandviken, County of Gävleborg in Sweden $\left(60^{\circ} 23^{\prime} 25.0^{\prime \prime} \mathrm{N}, 16^{\circ} 59^{\prime} 52.0^{\prime \prime} \mathrm{E}\right)$ on 6 September 2016. About 50 individuals were visually identified as Javesella sp. (by $10 \times$ magnifier glasses) and transferred for further studies to oat cultivar Ingeborg plants grown in a nylon-covered cage in laboratory greenhouse for future studies.

Host range tests. The progeny of the planthoppers kept on oat cultivar Ingeborg were used for host range tests involving spring wheat cultivars Vinjett and Zebra, rye cultivars Kaskelott and Amilo, triticale cultivar Algalo, spring barley cultivar Pongo, Alopecurus pratensis, Dactylis glomerata 'Luxor', Festuca rubra 'Sigmund', Lolium multiflorum 'Fredrik', Phleum pratense 'Ragnar', and Poa pratensis 'Kupol' (kindly provided by Lantmännen SW Seeds, Sweden). About 30 planthoppers (a mix of nymphs and adults) were transferred to each cage containing four seedlings of one species/ cultivar. Laboratory transmission tests were performed twice for each species/cultivar. After 3 weeks, young systemic leaves were collected and stored at $-80^{\circ} \mathrm{C}$. Planthoppers were collected and stored in $95 \%$ ethanol. The pictures of planthoppers were taken using Leica MZFL III stereomicroscope. The presence of the virus in collected materials was checked by RNA extraction and RT-PCR amplification with primers Tseg1_3553F and Tseg1_4329R targeting a 777-nt fragment in the RNA-dependent RNA polymerases (RdRp)-coding region of the virus (Supplementary Table S2).

Mechanical inoculations were performed by grinding about $1 \mathrm{~g}$ of infected leaf material (a pool of field-collected wheat leaf samples from Norway, collected in 2017) in $4 \mathrm{ml}$ of cold $0.03 \mathrm{M} \mathrm{Na}_{2} \mathrm{HPO}_{4}+$ $0.2 \%$ diethyldithiocarbamate (DIECA). In all, $75 \mathrm{mg}$ of $400 \mathrm{mesh}$ Carborundum and $75 \mathrm{mg}$ of activated charcoal powder were added before rub-inoculating the cotyledons or leaves of two to four young plants of wheat, oat, barley, maize, sorghum, melon, tomato, Chenopodium amaranticolor, C. quinoa, Nicotiana benthamiana, $N$. tabacum 'Xanthi', N. clevelandii, and N. glutinosa. The experiment was repeated at least twice for each species, and seven times for the natural host wheat. In order to test for the presence of the virus in wheat plants, back-inoculations were performed on the species $N$. benthamiana. For each species, uninoculated plants were included into the studies as negative controls. The plants were maintained in an insect-proof greenhouse and checked visually for symptom appearance. The presence of the virus was checked by RNA extraction and RT-PCR amplification from wheat and $N$. benthamiana samples with primers EWSMV-CP-F and EWSMV-CP-R targeting a 378-nt fragment in the nucleocapsidcoding region of the virus (Supplementary Table S2).

RNA extraction. Total RNA was extracted from individual field-collected cereal plant leaves using Trizol reagent (Invitrogen) or from a pool of three $N$. benthamiana plants using Tri Reagent (Molecular Research Center) according to manufacturer's protocols.

Total nucleic acids from the planthopper samples or planthoppertreated cereal and grass plant samples were extracted according to the protocol of (Oñate-Sánchez and Vicente-Carbajosa 2008) without DNase-treatment. DNase treatment was omitted to make it possible to use these same samples both for sRNA-based HTS analysis and DNA barcoding of a mitochondrial cytochrome c oxidase subunit I (COI) gene to confirm the vector species. The material from four plants grown in the same pot was pooled for the total RNA extraction. 
The quality of the purified nucleic acids was analyzed using a Nanodrop 2000 spectrophotometer (Thermo Scientific), and RNA integrity was verified by gel electrophoresis. Total RNA samples were used both for preparation of RNA-based libraries for the HTS and RT-PCR amplification for Sanger sequencing.

HTS of the small RNA (sRNA) or total RNA-based libraries. Total RNA extracted from field samples of cereal plants as well as planthoppers and planthopper-treated cereal plants from the greenhouse was used to build indexed cDNA libraries using TruSeq siRNA kit (Illumina) according to the Sample Preparation Guide 02/ 2013. Up to seven individual samples from the same field were pooled for each library. For each field, 1 to 2 libraries were synthesized. Amplified cDNAs between 140 and 160 bp were sequenced on HiSeq2500 rapid flowcell with $50 \mathrm{nt}$ single reads and cBot clustering (Illumina) at the Institute of Genomics, University of Tartu. Demultiplexing was done with CASAVA 1.8.2. (Illumina). The number of raw reads varied between 4.5 to 17.2 million for the sRNA libraries respective to the Estonian field samples. The number of raw reads in the two libraries made of viruliferous planthoppers and planthopper-treated plant samples from Hedesunda in Sweden were 71.9 and 41.7 million, respectively.

The total RNA extracted from $N$. benthamiana plants after four to six passages after being inoculated with wheat extracts (collected from Leirsund in Norway) was used to prepare a cDNA library using TruSeq stranded total RNA library Prep Plant kit (Illumina) according to manufacturer's instructions. The library was sequenced on a Nextseq500 sequencing machine at Liège University at $2 \times 150$ nt read length. Here, the number of raw reads was 4.8 million.

Clean reads were obtained from raw data by trimming adaptor sequences, discarding the low quality reads and ambiguous nucleotides ('N') at the end of reads and the reads with a length below $15 \mathrm{nt}$ using a BBDuk-Toolkit plugin implemented in Geneious Prime 2019.0.4 software (Biomatters Ltd.).

Bioinformatic analysis. For sRNA-seq data, the contigs were assembled de novo using the Oases 0.2.08 software (Schulz et al. 2012) varying the k-mer value from 15 to 31 as recommended (Massart et al. 2019). The assembled contigs were screened against the GenBank nucleotide collection and nonredundant protein sequences (nr) databases using BlastN and BlastX, respectively (https://blast.ncbi.nlm.nih.gov/Blast.cgi). The contigs showing the highest identity to tenuiviruses were aligned using the genome of rice stripe virus (RSV) as reference to assemble a draft sequence of the novel genome, later validated by Sanger sequencing of a fieldcollected isolate from an individual infected oat plant cultivar Pepino sampled on 28 June 2013 in Õru2, County of Valga, Estonia $\left(57^{\circ} 56^{\prime} 30.3^{\prime \prime} \mathrm{N}, 26^{\circ} 09^{\prime} 12.4^{\prime \prime} \mathrm{E}\right)$. For total RNA-seq data, the reads were paired then assembled de novo with Geneious Prime 2019.0.4.

Whole genome sequences from all libraries showing the presence of the novel tenuivirus were recovered by mapping HTS data on the Sanger-sequenced reference genome using Geneious Prime 2019.0.4. After assembly, open reading frames (ORFs) were identified using the "Annotate and Predict" function of Geneious software using the standard genetic code, a minimum of 100 codons and starting with AUG initiation codon. BlastP analyses were performed against NCBI nonredundant protein sequence database. A search for conserved domains was performed in Pfam database at https://www.genome.jp/tools/motif/.

Phylogenetic analyses were performed using the maximumlikelihood (ML) method using MegaX (Kumar et al. 2018). Construction of the trees was based on Muscle multiple sequence alignment. The best substitution model for deduced amino acid sequences of virus-encoded RdRp-s and nucleoproteins was selected with ModelTest included in MegaX. For the alignments and tree reconstruction, the sequences belonging to the homologous RNAs of the following viruses were retrieved from GenBank: (i) the tenuiviruses: Echinochloa hoja blanca virus (EHBV), Iranian wheat stripe virus (IWSV), maize stripe virus (MSpV), Urochloa hoja blanca virus (UHBV), rice hoja blanca virus (RHBV), rice grassy stunt virus (RGSV), rice stripe virus (RSV), wheat yellow head virus (WYHV; peptide sequence determined by a mass-spectrometry); (ii), the representatives of each genera of other Phenuiviridae members: Badu phasivirus (BADUV), Gouleako virus (GOLV), Hubei diptera virus 3 (HbDV-3), Hubei diptera virus 4 (HbDV-4), Hubei diptera virus 5 (HbDV-5), Hubei lepidoptera virus 1 (HbLV-1), Kabuto mountain virus (KAMV), Laurel Lake virus (LLV), Mothra virus (MTHV), Pidgey virus (PGYV), Rift Valley fever virus (RVFV), severe fever with thrombocytopenia virus (SFTSV), Wenzhou shrimp virus 1 (WzSV-1), Wuhan horsefly virus (WhHV); and (iii), the unassigned tentative phenuivirids (plant viruses): citrus coguvirus $(\mathrm{CCGaV})$, melon chlorotic spot virus (MeSCV), ramu stunt virus (RmSV), watermelon crinkle leaf-associated virus 1 (WCLaV-1), and watermelon crinkle leaf-associated virus 2 (WCLaV-2). The GenBank accession numbers can be found in Figure 1.

Confirmation by RT-PCR and Sanger sequencing. The draft genome sequence was used for designing primers allowing the amplification of the whole genome by RT-PCR (Supplementary Table S2). An individual oat plant sample positive for tenuivirus infection collected from Orru2, Estonia was selected for complementary Sanger sequencing to assemble a reference genome sequence.

The primer pair of Tseg1_3553F and Tseg1_4329R targeting a region in the RdRp gene of the novel virus was used for screening for tenuivirus infection in individual plant and planthopper samples by RT-PCR. The cDNA was synthesized using the corresponding reverse primer and RevertAid reverse transcription (Thermo Scientific) according to the manufacturer's instructions, while DreamTaq DNA polymerase (Thermo Scientific) was used for PCR $\left(95^{\circ} \mathrm{C}\right.$ for $3 \mathrm{~min}$, followed by 35 cycles of $95^{\circ} \mathrm{C}$ for $30 \mathrm{~s}, 60^{\circ} \mathrm{C}$ for $30 \mathrm{~s}, 72^{\circ} \mathrm{C}$ for $1 \mathrm{~min}$, with a final extension at $72^{\circ} \mathrm{C}$ for $7 \mathrm{~min}$ ). The size of the expected RTPCR product was $777 \mathrm{bp}$. After gel purification, the RT-PCR products were sequenced without subcloning at the Institute of Genomics, University of Tartu or at Macrogen Inc., Amsterdam.

Partial Sanger sequencing of the Leirsund isolate was performed on the RNAs extracted from the original wheat samples with primer TenuiV (De Miranda et al. 1994) targeting the highly conserved complementary extremities of tenuivirus genomes. RT-PCR was performed with the Takara One-step RT-PCR kit as described by Lecoq et al. (2019). PCR products from 1.2 to $2 \mathrm{~kb}$ were excised from agarose gel and cloned in the pGemT vector for Sanger sequencing with universal primers M13-21 and M13-Rev. For the complete amplification of RNA2, specific primers were designed along the fragment based on the reference sequence of the Estonian isolate. Both cloned and amplified fragments were sent for direct sequencing to Genoscreen (France). The sequences were assembled manually, based on the sequence from the reference Estonian isolate.

The individual planthoppers positive for tenuivirus infection were barcoded for the $5^{\prime}$ region of the mitochondrial COI gene using the primer pair of MLepF2_t1 and LepR1. The LepF2_t1/LepR1 primer pair is the most used one for barcoding of Hemiptera species (Gwiazdowski et al. 2015). A modified primer MLepF2_t1 contains also M13 primer binding site for direct sequencing of the PCR product (Hebert et al. 2013). The size of the expected PCR product was $668 \mathrm{bp}$. The amplification conditions were as follows: $95^{\circ} \mathrm{C}$ for $5 \mathrm{~min}$, followed by 35 cycles of $94^{\circ} \mathrm{C}$ for $30 \mathrm{~s}, 51^{\circ} \mathrm{C}$ for $30 \mathrm{~s}, 72^{\circ} \mathrm{C}$ for $1 \mathrm{~min}$, with a final extension at $72^{\circ} \mathrm{C}$ for $10 \mathrm{~min}$. Gel purification of the PCR products and Sanger sequencing were done as described above.

The sequenced COI barcodes were used for verification of the planthopper species using megablast search against GenBank nonredundant nucleotide collection, and for a tree-based animal identification using the BOLD Identification System at http:// www.boldsystems.org/.

\section{RESULTS}

Identification of a novel tenuivirus and genome characterization. De novo assembled contigs presenting homologies with tenuivirus RNA segments were identified both 
in sRNA-based and total RNA-based HTS libraries. The highest number of contigs (378) having a match with tenuiviruses according to BlastX analysis was found in a library corresponding to the samples collected from Oru2 in Estonia. The longest de novo assembled contig characteristic of tenuiviruses was 2,563nucleotides (nt) long having $91 \%$ query coverage with $31 \%$ of identities (E-value: $5 \mathrm{e}-$ 101) to RHBV segment 1 (GenBank accession number YP_ $009449440)$ and $89 \%$ query coverage with $32 \%$ of identities

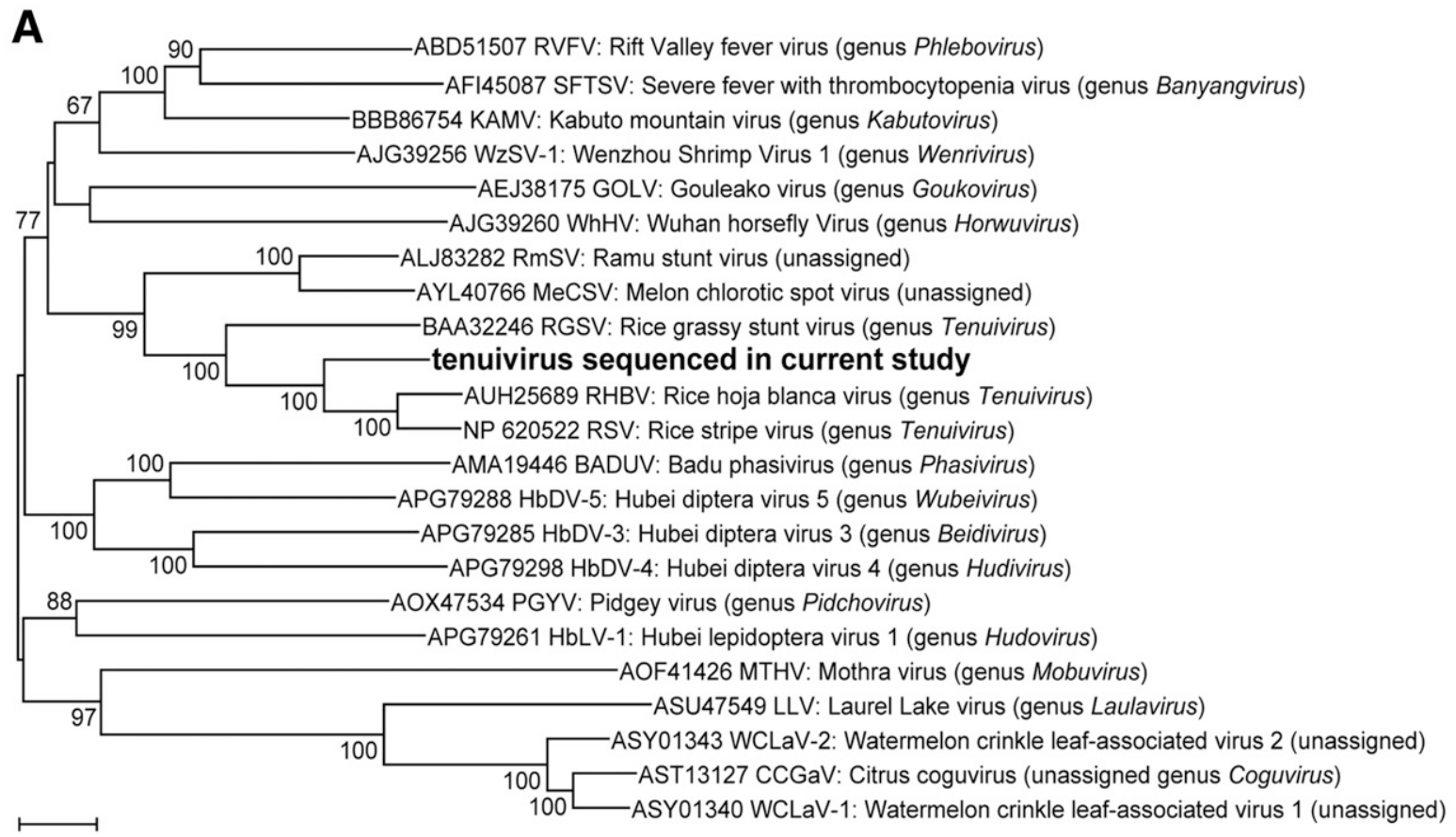

0.50

B

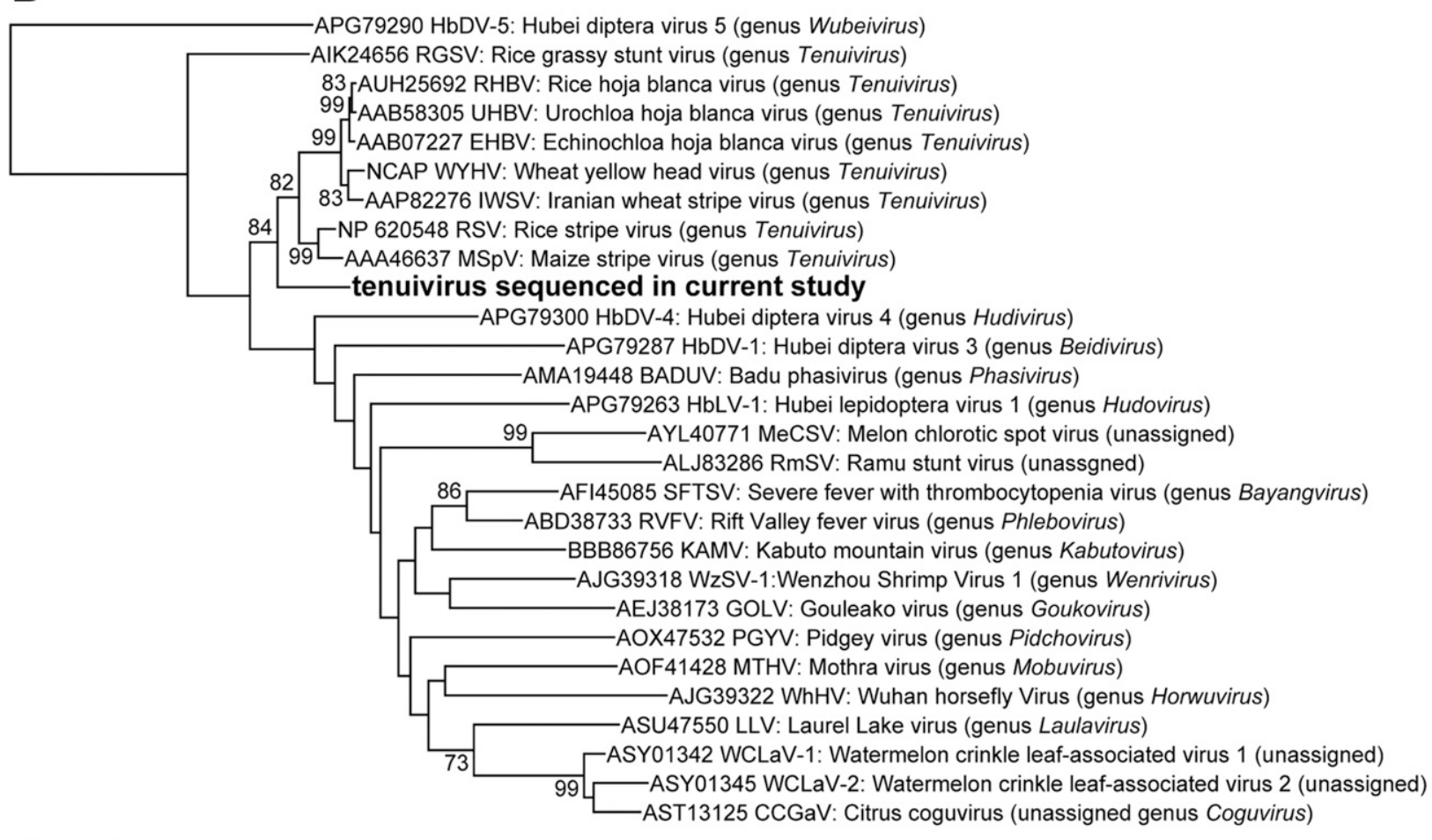

Fig. 1. Evolutionary analysis of phenuiviruses based on deduced amino acid sequences of their A, RNA-dependent RNA polymerases, and B, the nucleocapsid proteins were conducted in MEGAX (Kumar et al. 2018). Analysis involved the members of the genus Tenuivirus, one representative of each genera in family Phenuiviridae, and unassigned plant viruses showing sequence homology with the members of Phenuiviridae. The novel tenuivirus sequenced in this study is indicated in bold font. The evolutionary history was inferred by using the maximum likelihood method and General Reverse transcription + Freq. model (for RdRp-s) or by using the maximum likelihood method and Le_Gascuel_2008 model (for N-proteins). Initial tree(s) for the heuristic search were obtained automatically by applying neighbor-join and BioNJ algorithms to a matrix of pairwise distances estimated using a JTT model, and then selecting the topology with superior log likelihood value. A discrete Gamma distribution was used to model evolutionary rate differences among sites (four categories $+\mathrm{G}$ ). Bootstrap values (500 replicates) greater than $70 \%$ are indicated for each node. The scale bar represents the average number of substitutions per site. 
(E-value: 9e-94) to RSV segment 1 (GenBank accession number AWN09230). It was possible to assemble a draft genome of the novel virus (for designing the genome-wide set of primers) using the sequence of RSV as a reference as follows: segment 1 was covered by 9 overlapping contigs, segment 2 was covered by 2 contigs with a gap up to $200 \mathrm{nt}$ between them, segment 3 was covered by 2 overlapping contigs, and segment 4 was composed of one $1891 \mathrm{nt}$ long contig.

One individual plant sample collected from Õru2 (Estonia) that was positive for tenuivirus infection in RT-PCR was subjected for the full genome Sanger sequencing to obtain a reference sequence.

The viral genome obtained by Sanger sequencing consists of four RNA segments (GenBank accession numbers MN044342 to MN044345) for a total size of 16,898 nt. Characteristic of tenuiviruses, all these segments share conserved complementary 5' and $3^{\prime}$ termini: 5' -ACACAAAGUCCAGGG...CCCUGACUUU GUGU-3' (the sequences conserved for all tenuiviruses are underlined). The nucleotide sequence comparison of the four RNA segments with other tenuiviruses species revealed the highest percentage of identities with RSV and RHBV for segment 1 (48.3 to
48.4\%), with MSpV for segment 2 (44.1\%), with UHBV and RHBV for segment 3 (41.8 to $42 \%$ ) and with EHBV, UHBV, and IWSV for segment 4 (46.8 to $46.9 \%$ ). For all segments, the lowest identities were seen with RGSV (Table 1).

Each of the four genomic RNA segments encode two putative ORFs, one on the viral and one on the complementary strand based on sequence similarity with other tenuivirus genomes (Table 2 and Supplementary Table S3).

On RNA1, the putative large ORF encoding $\mathrm{pC} 1$ has a bunyavirus RdRp-like domain and it shares the highest amino acid sequence identity (46\%) both with RHBV RdRp (accession number YP 009449440.1) and RSV RdRp (accession number ACG58336.1) (Table 3). Viral strand encoded $\mathrm{pV} 1$ presents a domain similar to plant NAM/NAC-like transcription factors that regulate downstream genes involved in plant development as well as in defense or tolerance responses to biotic and abiotic stresses (Nuruzzaman et al. 2013). Identity with RGSV pV1 is very low (14.8\%). RNA1s of RSV and RHBV do not encode pV1.

The two proteins encoded by RNA2, pV2 and pC2, share the highest identity (33 to 36\%) with RSV pNS2 (accession number

TABLE 1. Identity percentages of complete nucleotide sequences of segments RNA1, RNA2, RNA3, and RNA4 of the novel tenuivirus (GenBank accession numbers MN044342 to MN044345) with the corresponding RNA segments of other tenuiviruses ${ }^{\mathrm{a}}$

\begin{tabular}{|c|c|c|c|c|c|}
\hline Virus & Abbreviation & RNA1 & RNA2 & RNA3 & RNA4 \\
\hline Maize stripe virus & MSpV & ND & 44.1 & 40.7 & 40.1 \\
\hline Rice stripe virus & RSV & 48.3 & 43.8 & 37.6 & 40.7 \\
\hline Rice hoja blanca virus & RHBV & 48.4 & 41.8 & 42.0 & 46.1 \\
\hline Urochloa hoja blanca virus & UHBV & ND & ND & 41.8 & 46.8 \\
\hline Iranian wheat stripe virus & IWSV & ND & 43.8 & 40.2 & 46.9 \\
\hline Rice grassy stunt virus & RGSV & 43.8 & 34.3 & $35.7^{\mathrm{b}}$ & $32.5^{\mathrm{b}}$ \\
\hline
\end{tabular}

a The following genome sequences of tenuiviruses were retrieved from NCBI GenBank for identity percentage calculations: MSpV (RNA2: MSU53224, RNA3: AJ969410, RNA4: MZSNCPNS4P), RSV (RNA1: NC_003755, RNA2: NC_003754, RNA3: NC_003776, RNA4: NC_003753), RHBV (RNA1: MG566074, RNA2: MG566075, RNA3: MG566076, RNA4: MG566077), EHBV (RNA3: EHBPV3G, RNA4: EHBPC44NCP), UHBV (RNA3: U82447; RNA4: U82446), IWSV (RNA2: AY312434, RNA3: AY312435, RNA4: AY312436), and RGSV (RNA1: AB009656, RNA2: AB010376; RNA5: AB000403, RNA6: AB000404).

b RGSV RNA5 and RNA6 were used for calculations of sequence identities as these are equivalent to RNA3 and RNA4 of other tenuiviruses, whereas RGSV RNA3 and RNA4 are unique (Toriyama et al. 1998). ND: not determined because the sequence of the corresponding virus is not available.

TABLE 2. Features of the open reading frames (ORFs) of the novel tenuivirus genome

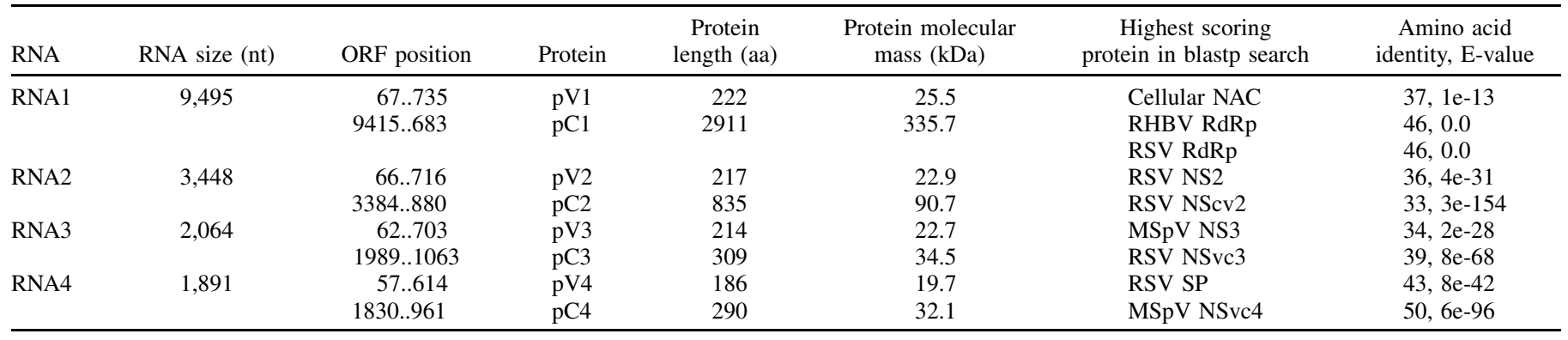

TABLE 3. Amino acid percentage identity calculations based on Muscle multiple sequence alignments of the protein sequences of the novel tenuivirus and the respective sequences of other tenuivirus proteins ${ }^{\mathrm{a}}$

\begin{tabular}{|c|c|c|c|c|c|c|c|c|}
\hline Novel virus & pV1 (NS1) & pC1 (RdRp) & $\mathrm{pV} 2$ (NS2) & $\mathrm{pC} 2(\mathrm{NScv} 2)$ & pV3 (NS3) & $\mathrm{pC} 3(\mathrm{~N})$ & pV4 (NS4; SP) & pC4 (NScv4) \\
\hline MSpV & ND & ND & 28.0 & 30.6 & 29.9 & 35.4 & 41.5 & 48.4 \\
\hline RSV & - & 31.1 & 30.3 & 30.2 & 29.1 & 37.6 & 39.9 & 44.8 \\
\hline RHBV & - & 30.9 & 28.0 & 31.1 & 27.6 & 31.4 & 40.8 & 46.2 \\
\hline UHBV & ND & ND & ND & ND & 26.6 & 32.1 & 40.8 & 46.2 \\
\hline IWSV & ND & ND & 27.1 & 30.6 & 27.9 & 31.0 & 41.4 & 45.5 \\
\hline WYHVb & ND & ND & ND & ND & ND & 33.1 & ND & ND \\
\hline $\mathrm{RGSV}^{\mathrm{c}}$ & 14.8 & 32.2 & 18.0 & 20.6 & 16.7 & 17.4 & 26.0 & 19.5 \\
\hline
\end{tabular}

a Maize stripe virus (MSpV), rice stripe virus (RSV), rice hoja blanca virus (RHBV), Echinochloa hoja blanca virus (EHBV), Urochloa hoja blanca virus (UHBV), Iranian wheat stripe virus, wheat yellow head virus (WYHV), and rice grassy stunt virus (RGSV). ND = not determined.

b WYHV is a tentative tenuivirus and the amino acid sequence of its nucleocapsid protein has been determined by mass spectrometry without genome sequencing (Seifers et al. 2005).

${ }^{c}$ The protein sequences encoded by RNA5 and RNA6 of RGSV were used for calculations of amino acid identities as they are supposed to be equivalent to the proteins encoded by RNA3 and RNA4 of other tenuiviruses (Toriyama et al. 1998). 
YP_009507898.1) and RSV NSvc2 (accession number ACG58324.1), respectively (Table 3). RSV NS2 is a membraneassociated protein, which interacts with nucleolar fibrillarin and may promote systemic virus infection in plants through this interaction (Zheng et al. 2015). RSV NScv2 is a glycoprotein targeted to the ER membrane and it is supposed to control ribonucleoprotein (RNP) maturation in plants (Yao et al. 2014). NSvc2 is also an essential helper component that ensures a proper interaction between RSV RNPs and the midgut cells in vector body for its circulative and propagative transmission ( $\mathrm{Lu}$ et al. 2019).

RNA3 encodes two proteins, $\mathrm{pV} 3$ and $\mathrm{pC} 3$; pV3 shares the highest identity (34\%) with MSpV NS3 (accession number AEX91905.1) and pC3 shares the highest identity (39\%) to RSV NSvc3 (accession number AAM49587.1) (Table 3). The NS3 proteins of RSV and RHBV act as silencing suppressors (Hemmes et al. 2007; Xiong et al. 2009), whereas RSV NSvc3, a nucleocapsid protein $(\mathrm{N})$, is thought to be the major determinant of initial insect-virus interactions by playing a critical role in interactions with the cuticular proteins of the insect alimentary canal and in endocytosis of viral RNPs (Huo et al. 2014; Liu et al. 2015).

RNA4 encodes two proteins, pV4 and pC4; pV4 shares the highest identity (43\%) with RSV disease specific protein (SP) (accession number AAP38205.1) and $\mathrm{pC} 4$ shares the highest identity $(50 \%)$ to $\mathrm{MpSV}$ NSve4 (accession number $\mathrm{YP}_{-}$ 009507901.1) (Table 3). RSV SP is essential for virus movement in vector tissues. It is involved in the formation of cytoplasmic inclusions, which interact with the viral N-protein, a protein component of viral RNPs (Wu et al. 2014). RSV NSvc4 and the corresponding protein encoded by RGSV RNA6 are known as the viral movement proteins in plants (Xiong et al. 2008).

Phylogenetic analyses. In phylogenetic analyses based on their RdRp and nucleoprotein amino acid sequences, the novel virus clustered with tenuiviruses within the family tree of Phenuiviridae (Fig. 1). It appears distinct from known tenuivirus species, and more related to typical tenuiviruses (RSV, RHBV) than to the more distant RGSV or to the unassigned tenui-like viruses RmSV and MeCSV. The RdRp-s of tenuiviruses and of these two tenuiviruslike viruses cluster together with a high support (99\%), whereas their nucleoproteins are more distant (Fig. 1).

Prevalence and molecular diversity. The Sanger-sequenced reference genome sequenced from one individual plant sample was used for mapping all HTS libraries. The novel tenuivirus was identified in 13 and 2 sRNA-based HTS libraries from Estonian and Swedish samples, respectively. Both Swedish libraries corresponded to the same isolate: one of these libraries was made of the planthoppers carrying the virus and the other was corresponding to a mix of barley cultivar Pongo, wheat cultivar Vinjett, and rye cultivar Amilo used for feeding the planthoppers. In addition, the same virus was also detected in the total RNA-based library of sample from Leirsund in Norway (the library was corresponding to infected $N$. benthamiana several passages after being inoculated with an extract of field-collected wheat plants). The geographical locations of the tenuivirus detections are shown in Figure 2.

Read mapping to the reference genome indicated that there was no strong strand bias toward (+) or (-) strand for any of the genome segments. For cereal plant samples, the most abundant size class of the viral small RNA reads was $21 \mathrm{nt}$, whereas it was $22 \mathrm{nt}$ for the only planthopper sample. This result is in concordance with the previously collected data that indicate accumulation of 21- and 22-nt siRNAs during viral siRNA biogenesis in case of plant RNA viruses (Pooggin 2018).

The full or nearly full genome was assembled for the majority of the isolates, except for Meeri, Avinurme 4b, and Leirsund samples (Supplementary Table S4). Genome sequencing depth was overall

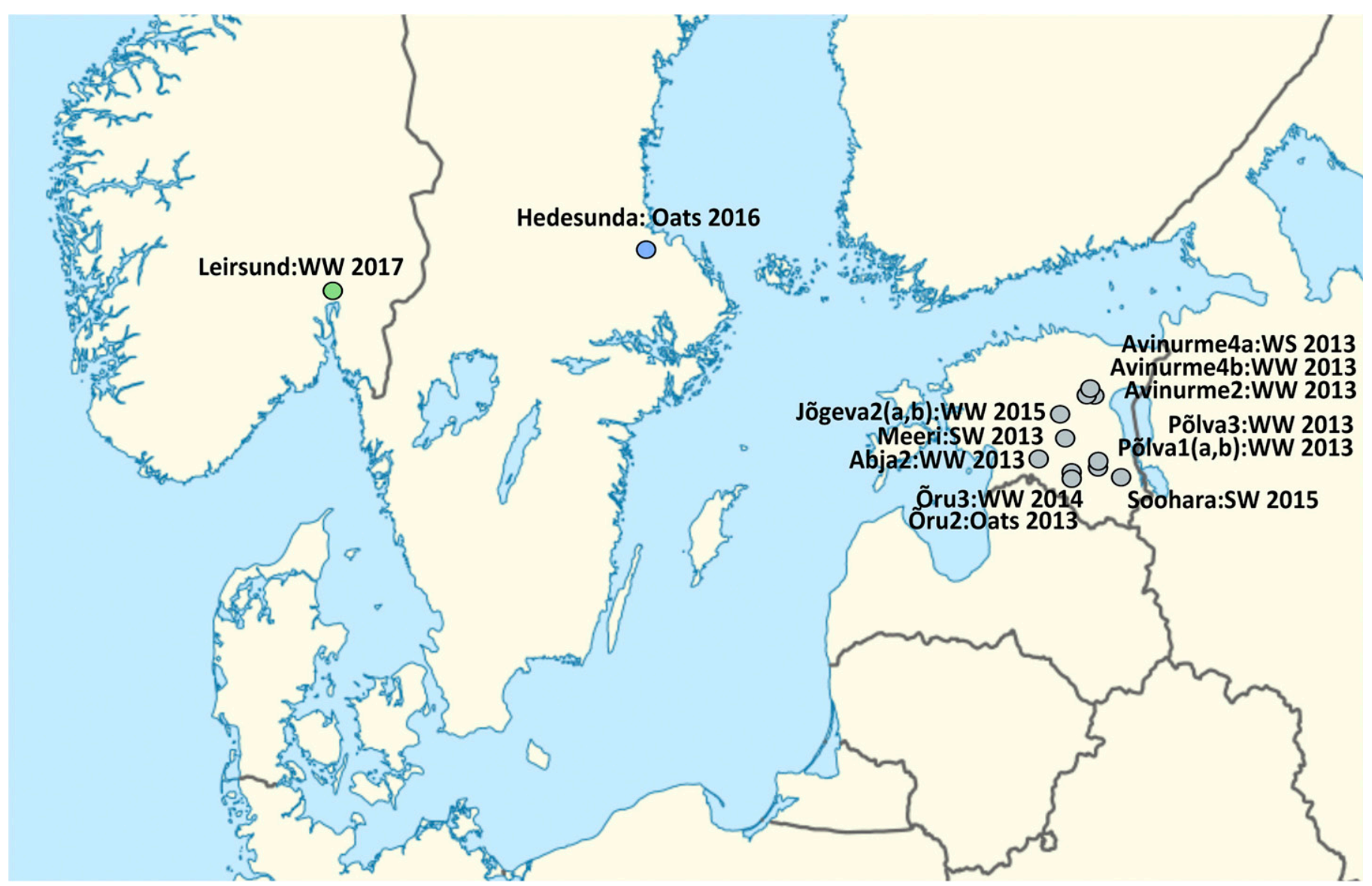

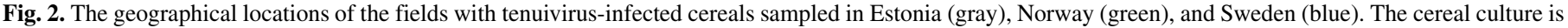
indicated together with the sample collection year and place. SW, spring wheat; WW, winter wheat; and WS, winter spelt. 
low for the Meeri isolate, probably because of low virus concentration in the sample (this was the only sample that remained virus-negative in RT-PCR, results not shown). Remarkably low sequencing depths were seen for genome segment 2 of the isolates Avinurme $4 \mathrm{a}$ and $4 \mathrm{~b}$ ( 2.9 and $1.2 \mathrm{nt}$ per position, respectively) and genome segment 4 of the Avinurme $4 \mathrm{~b}$ (4.3 nt per position) (Supplementary Table S4). It was not possible to assemble the sequences of the segments 2 and 4 for Avinurme $4 \mathrm{~b}$ isolate. In Leirsund sample that represents infected $N$. benthamiana plants (several passages after being inoculated with an extract of fieldcollected wheat plants), no match was obtained with RNA2 (Supplementary Table S4). For that isolate, the full-length sequence of RNA2 was obtained by Sanger sequencing of the original wheat sample.

The complete assembled consensus sequences (GenBank accession numbers MN160329 to MN160390) were aligned for each genome segment to identify the phylogenetic relationships between isolates. The genome segments of all analyzed isolates shared more than $92 \%$ identity with the respective segments of the others, showing that they belong to the same species (Fig. 3). Consensus genome sequences from the plant and planthopper samples containing the same Hedesunda isolate had $98.3 \%$ of identity with each other for RNA2 and 99.6 to $100 \%$ of identity for other genome segments. The Hedesunda isolate sequenced from the plant sample was used in further pairwise sequence comparisons with other isolates.

Pairwise sequence comparisons of the isolates indicated that RNA1 was grouped in two subtypes, whereas RNA2, RNA3, and RNA4 were grouped in three subtypes each (Fig. 3). Estonian isolates, except the ones collected from Avinurme, shared the highest identities with each other and with the Leirsund isolate from Norway for RNA1, RNA2, and RNA3. For RNA4, the Estonian Soohara isolate and the Norwegian Leirsund isolate had slightly lower identity with this Estonian isolate group (ca. 96\%) and they formed a group of their own (with $98.2 \%$ of identity).

Avinurme isolates from Estonia showed higher identities (ca. 99\%) to the Hedesunda isolate from Sweden than to the other Estonian isolates (ca. 93\% of identity) for RNA1. For RNA2, the Avinurme isolates grouped to a separate subtype having ca. 94 to $95 \%$ of identity with the other Estonian isolates and with the Swedish Hedesunda isolate as well. RNA2 of Hedesunda isolate formed a separate group. For RNA3, Avinurme 2 and 4b isolates had high homology (99\%) with the Hedesunda isolate from Sweden, whereas Avinurme 4a isolate formed a group of its own having 95 to $96 \%$ of identity with other isolates. For RNA4, Avinurme 4a isolate grouped with the other Estonian isolates whereas Avinurme 2 isolate shared higher identity with the Swedish Hedesunda isolate (97.6\%).

Complete loss of RNA2 of EWSMV after several passages on $N$. benthamiana. For the Norwegian sample from Leirsund maintained on $N$. benthamiana, complete sequences of fragments 1,3, and 4 were obtained both after de novo assembly and after mapping of paired reads to the Estonian reference genome. Surprisingly, no reads or contigs were found to match with RNA2. Specific primers were designed against the different fragments and used on RNA extracts from the original wheat samples, from the first $N$. benthamiana inoculated from wheat, from the different $N$. benthamiana used for HTS sequencing and from $N$. benthamiana maintained in the greenhouse after serial inoculations (every 1 to 2 months), more than 1 year after the first inoculation from wheat. No RNA was kept from the intermediate $N$. benthamiana between the second and 8 months after the first inoculation, so no test could be performed for the detection of RNA2 in these plants. RNA2 was detected in the original wheat sample and the first mechanically inoculated $N$. benthamiana, but not in the greenhouse $N$. benthamiana infected after several passages on that host nor in the pool of $N$. benthamiana samples used for HTS. The full-length sequence of RNA2 was obtained by Sanger sequencing of RT-PCR amplifications from wheat and the first $N$. benthamiana inoculated from wheat.
Identification of the vector species. In autumn 2016, a population of planthoppers morphologically identified as Javesella sp. was collected from an oat field in Hedesunda in Sweden and transferred to oat cultivar Ingeborg plants in a greenhouse. After 16 days, these plants showed symptoms of possible virus infectionchlorotic stripes and mottling. RT-PCR analysis with a primer pair designed to target a region in the RdRp gene of the novel cerealinfecting tenuivirus amplified a 777-bp fragment from the laboratorygrown test plants (not shown). The sequence showed an identity of $93 \%$ to the respective sequence of the tenuivirus from Estonia.

After 1 month, the second generation of the planthoppers (nymphs) were transferred to new oat plants of cultivar Ingeborg. After the plants began to show a development of chlorosis, 16 individual planthoppers were used for nucleic acid extraction. Using the primer pair targeting the RdRp gene, a cDNA fragment of the expected size was amplified for 8 of 16 planthopper samples subjected for the tenuivirus detection (not shown). The correct identity of the amplification products were confirmed by sequencing of the amplification products for three random samples.

Sequencing of the COI specific PCR amplification products from the tenuivirus-positive planthopper samples indicated a barcode characteristic of either Nothodelphax sp. or Javesella sp. (circa 95\% identity with both). In parallel, tree-based identification of the sequenced samples using the BOLD Identification Systems for animal COI records identified the planthopper samples as $J$. pellucida. The photographs of the same planthoppers were examined closer for the morphological characteristics, and they were characteristic of Javesella (Supplementary Fig. S1).

Symptoms on infected plants and host range tests. In field conditions, the infected plants showed chlorosis, stunting, and reduced heading or no head emergence (Fig. 4A to $\mathrm{C}$ and $\mathrm{F}$ ).

Progeny of the field-collected viruliferous planthoppers was used to study the host range of the Hedesunda isolate in experimental conditions to compare with previous studies (Ikäheimio 1964; Slykuis and Watson 1958; Vacke and Průša 1961). None of the planthopper-infested grasses (Alopecurus pratensis, Dactylis glomerata 'Luxor', Festuca rubra 'Sigmund', Lolium multiflorum 'Fredrik', Phleum pratense 'Ragnar', and Poa pratensis 'Kupol') showed either visible symptoms of virus infection or were viruspositive in RT-PCR analyses performed 3 weeks after inoculation. On the other side, sequencing confirmed infection of all seven experimentally inoculated cereal cultivars (oat cultivar Ingeborg, wheat cultivars Vinjett and Zebra, triticale cultivar Algalo, rye cultivars Kaskelott and Amilo, and barley cultivar Pongo) (not shown). In greenhouse conditions, the infection symptoms were most clearly displayed on wheat where infection usually led to strong chlorosis, dwarfing and reduced heading or no head emergence (Fig. 4E). Single infection by the studied virus was confirmed by HTS analysis of a mixed sample composed of infected plants of barley (cultivar Pongo), wheat (cultivar Vinjett), and rye (cultivar Amilo). The plants treated by nonviruliferous leafhoppers that were confirmed as virus-negative in RT-PCR showed the signs of insect feeding but no chlorosis or problems in stalk and head formation (Fig. 4D).

Using mechanical inoculations, the Leirsund isolate was inoculated to several monocot and dicot plants. No symptoms were observed and no virus was detected by RT-PCR in any of the graminaceous hosts tested (wheat, barley, sorghum, oat, and maize), showing that mechanical inoculation of the virus on its natural hosts is poorly efficient, as often described for tenuiviruses. However, N. benthamiana showed numerous local and systemic chlorotic spots and vein clearing, developing toward necrosis of the leaves and eventually plant death (Fig. 4G). N. tabacum 'Xanthi', and N. clevelandii, displayed occasionally few necrotic lesions on the inoculated leaves but not at the plant apex. Accordingly, infection was confirmed in the inoculated leaves but not at the apex by RT-PCR using primers targeting RNAs 3 and 4 (not shown). Back-Inoculation to $N$. benthamiana confirmed the presence of infectious virus in tobacco and $N$. benthamiana and its 
absence in wheat. HTS analysis did not detect any other viruses in $N$. benthamiana. No infection symptoms were observed in the other dicot hosts (tomato, melon, $N$. glutinosa, Chenopodium amaranticolor, and $C$. quinoa) (not shown).

\section{DISCUSSION}

In the current study we identified a tenuivirus genome from fieldgrown cereal crop plants showing chlorosis, stunting, and disturbance in head formation. HTS data analysis identified only a single plant virus infection in most of the samples, indicating that the novel virus can be the cause of disease symptoms. The same virus was found in field-collected planthoppers. The planthoppermediated virus transmission was confirmed by laboratory experiments. Different cereal test plants treated with viruliferous planthopper culture developed chlorosis and stunting, reproducing the original symptoms observed in field-infected plants and confirming the virus as the etiological agent of the disease.

Sequencing of COI barcodes of virus-positive planthoppers identified J. pellucida as the vector of this virus. J. pellucida and several other Javesella species are known as polyphagous insects circulating between grasses and cereals. J. pellucida is considered one of the most common planthopper species feeding on smallgrain cereals in temperate Holarctic region. The yield losses caused by $J$. pellucida have mainly been related to transmission of plant viruses and phytoplasmas and not by the damage caused by the feeding itself (Raatikainen 1967).

Our discovery of a cereal-infecting tenuivirus transmitted by $J$. pellucida strongly suggests that it corresponds to EWSMV, which was biologically characterized but not sequenced in the 1950-60s. Our virus transmission assays with $J$. pellucida showed that all of the cereal species under study were successfully infected as it was

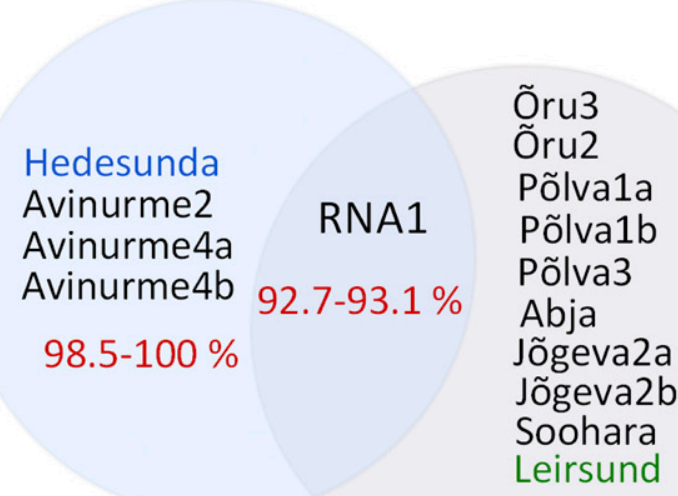

99.2-99.9\%

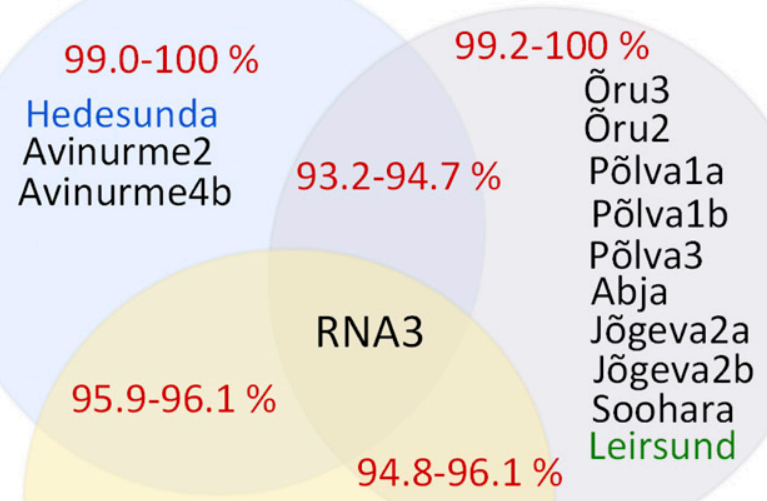

Avinurme4a
$99.9 \%$
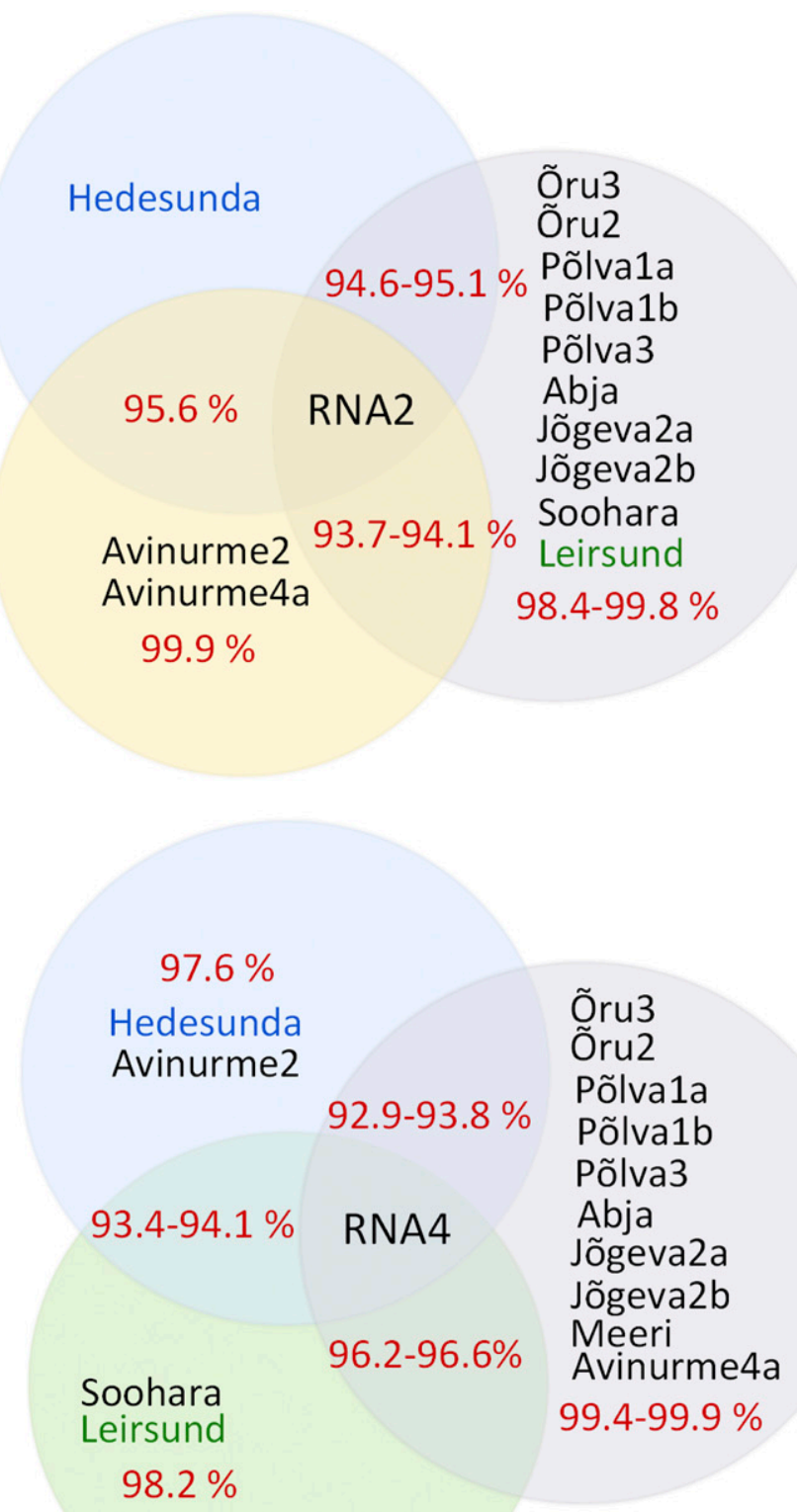

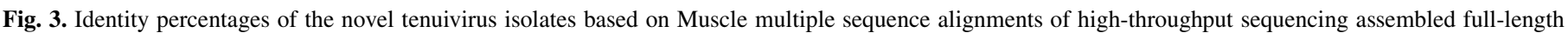

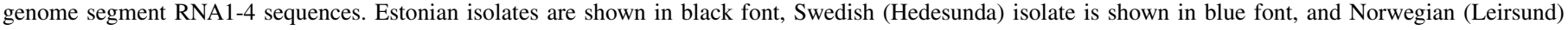

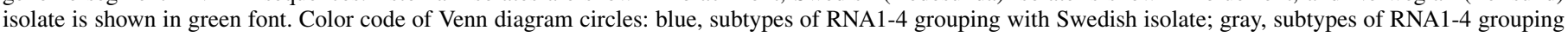

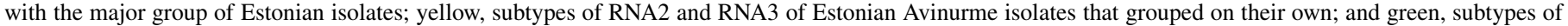
RNA4 grouping with Norwegian isolate. 
observed earlier for EWSMV. In addition to the cereal crops, we tested the susceptibility of several pasture grass species. None of these species became infected. In earlier studies, these grass species were also not susceptible to EWSMV in experimental conditions, except $L$. multiflorum plants that developed the disease symptoms in small proportion of plants (11\%) (Vacke and Průša 1961). At the same time, up to $32 \%$ of L. multiflorum plants were reported to display EWSMV-like symptoms in affected pastures (Vacke and Průša 1961). One possible explanation for this phenomenon can be that the cultivars used for the experimental assays were less

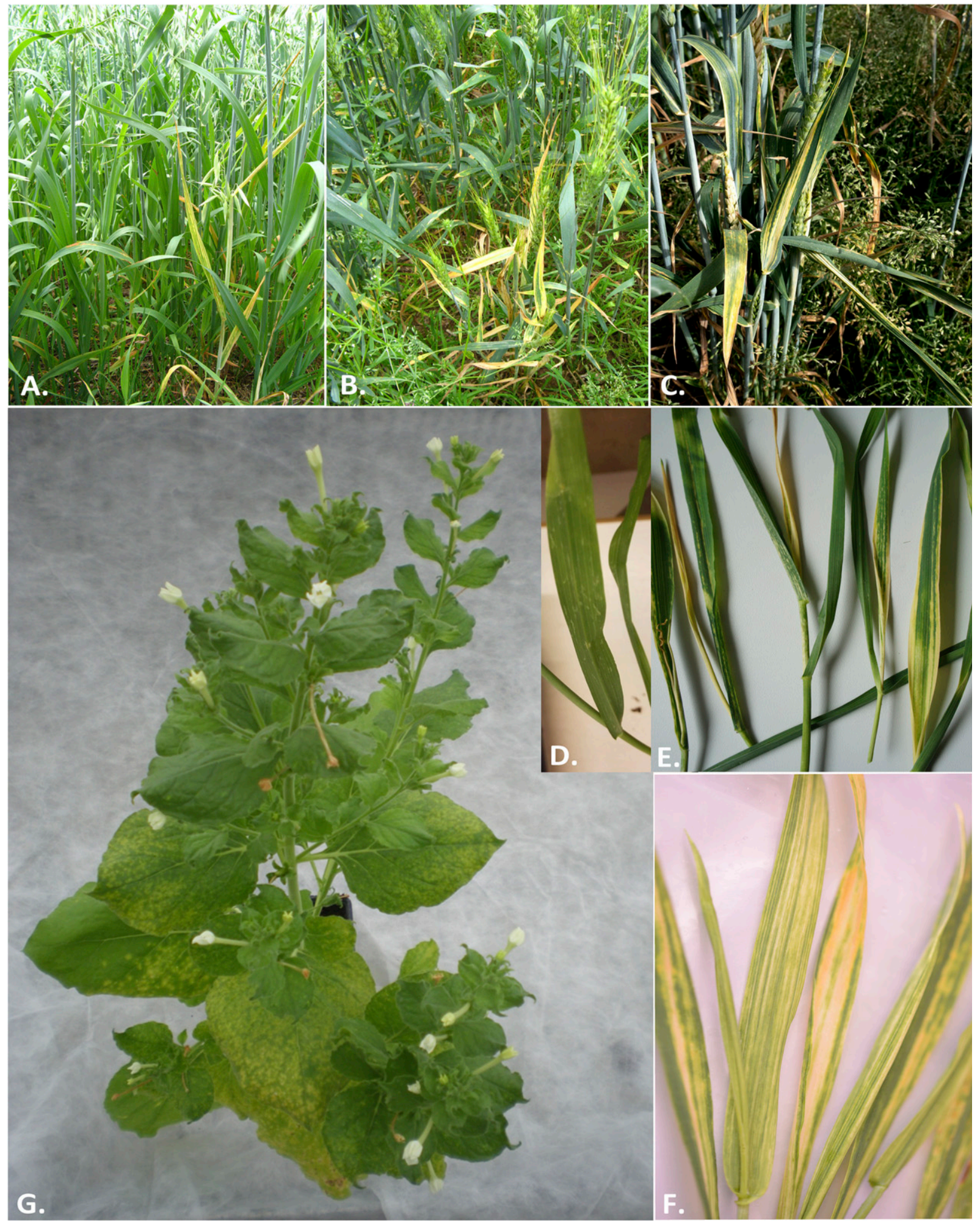

Fig. 4. European wheat striate mosaic virus-infected plants. The photographs were taken during the sample collection. A, Stunted and chlorotic oat plant cultivar Pepino in the field at Orru2, Estonia (2013); B, stunted and chlorotic wheat plants cultivar Skagen with reduced heading in the field at Põlva1, Estonia (2013); C, stunted and chlorotic wheat plants cultivar Jantarka with reduced heading in the field at Leirsund, Norway (2017); D, healthy wheat plant cultivar Zebra, treated with nonviruliferous planthoppers (laboratory virus transmission experiment with Hedesunda isolate from Sweden); E, chlorotic wheat plants cultivar Zebra with no head emergence at 6 weeks after treatment with virus-infected planthoppers (laboratory virus transmission experiment with Hedesunda isolate from Sweden); $\mathbf{F}$, close-up picture of the leaves of symptomatic wheat cultivar Skagen collected from Jõgeva2, Estonia (2015) showing the development of striate mosaic chlorosis; and $\mathbf{G}$, yellow spots on systemic leaves of Nicotiana benthamiana after mechanical inoculation 2 months after inoculation with the Leirsund isolate. 
susceptible than those infected in natural conditions. Alternatively, EWSMV-like disease of $L$. multiflorum seen in affected pastures may have been caused by another unidentified virus. Indeed, $P$. pratense that did not develop any symptoms in greenhouse tests was suggested to be frequently infected in nature (Ikäheimio 1964; Slykuis and Watson 1958; Vacke and Prǔša 1961) but the symptoms in natural conditions appeared caused by another virus, Phleum green stripe virus (PGSV) transmitted by the delphacid planthopper Megadelphax sordidula (Heikinheimio and Raatikainen 1976). Unfortunately, it was not possible to compare the sequence data with the historical samples as there are no samples stored until today in laboratory or biological resource collections according to our personal communications with M. Adams from ICTV, A. Fox from FERA Science Ltd. (UK), M. Jeżewska (Inst. of Plant Protection, Poland), W. Menzel from DMSZ Plant Virus Collection (Germany), C. Plopa (RIFG Pitesti, Romania), P. Redinbaugh from USDA, and J. Valkonen from University of Helsinki (Finland).

According to the similarities in infection biology, EWSMV was first recognized as a tentative member of tenuivirus group (Gingery 1987) and subsequently included on a list of tentative members of genus Tenuivirus (Toriyama 1995). According to the current knowledge, tenuiviruses are transmitted to the host plants only by their delphacid planthopper vectors in a persistent-propagative manner. Each tenuivirus species seems to be highly specialized to one or a few particular vector species. Interestingly, among currently recognized members of genus Tenuivirus, most are important cereal crop pathogens associated with planthopper vectors who themselves are important pests of cereal crops. The maize pathogen $\mathrm{MSpV}$ is worldwide transmitted by Peregrinus maidis (Gingery et al. 1981), the rice pathogens RSV and RGSV are widely distributed in Asia, respectively, by Laodelphax striatellus and Nilaparvata lugens (Otuka 2013) and the rice-infecting RHBV is spread in tropical and subtropical America by Tagosodes orizicolus (Morales and Jennings 2010). As J. pellucida is abundant and widely spread species in temperate climate, the previous findings of EWSMV in several European countries are not surprising. It is more intriguing why it has not been noticed any more since 1970s until now when we discovered it simultaneously from three countries. Mild infections and lack of identification tools are the most apparent answers. On the other hand, the cyclic nature of the epidemics can be also a reason, as was the case for RHBV that has been observed to go through several outbreak and fading phases since its discovery in the 1950s (Morales and Jennings 2010).

Sequencing and assembly of EWSMV genome indicated that it has four genomic segments, like most tenuiviruses. The isolates found from different countries had approximately $92 \%$ nucleotide sequence identity at the genome level, confirming that they belong to the same species. Phylogenetic analyses of different genome segments and two of the proteins (RdRp and N-protein) encoded by EWSMV indicated that it clusters with the recognized members of the genus Tenuivirus, being more closely related to RSV and MSpV than to RHBV, EHBV, UHBV, IWSV, or WYHV.

Among seven previously sequenced tenuivirus species, three are fully sequenced. Complete sequences are also available for two tenui-like viruses RmSV and MeCSV presenting a low sequence similarity with the other tenuiviruses as well as a high number of genomic segments (6 and 8, respectively, for RmSV and MeCSV). The other partially characterized tenuiviruses lack data on the longest segment, RNA1, and sometimes also on RNA2. RNA1 of both RGSV and EWSMV encode possibly one extra protein in addition to the viral RdRp. However, identity between these proteins encoded by the novel tenuivirus and RGSV is very low (14.8\%). Intriguingly, the protein V1 encoded by EWSMV displays some sequence similarity with NAC transcription factors. The NAC gene family members have been suggested to play important roles in regulation of the transcriptional reprogramming associated with plant development and stress responses. Also, they can either enhance or inhibit virus multiplication via direct interaction with virus-encoded proteins (Nuruzzaman et al. 2013). Upregulation in large numbers of rice NAC genes has been shown in response to RSV or RGSV infection (Nuruzzaman et al. 2010, 2015). Therefore, it would be interesting in the future to reveal whether EWSMV pV1 has any role related with regulation of the plant stress responses. Whether RNA1 encoded EWSMV and RGSV V1 proteins share similar functions or not, remains to be studied.

In our study, successful mechanical inoculation of EWSMV was performed using $N$. benthamiana, which is not a natural host species for EWSMV but is particularly susceptible to a wide range of plant viruses. Indeed, $N$. benthamiana could also be inoculated mechanically by RSV (Lu et al. 2018). Upon EWSMV mechanical inoculation, plants displayed symptoms of yellow spots and vein clearing evolving in necrosis, and eventually leading to plant death. Surprisingly, RNA2 was apparently lost after serial mechanical inoculations on $N$. benthamiana and could not be detected either by HTS or by RT-PCR amplification using specific primers, whereas it was present in the original wheat sample and after the first inoculation of $N$. benthamiana. The reassortment of segments is a well described phenomenon for viruses in the Bunyavirales order (Briese et al. 2013) and missing segments have been observed with bunyaviruses (Borucki et al. 1999). Reassortment of the genome segments has been detected for RSV (Jonson et al. 2011) but to our knowledge, this is the first observation of a missing segment for a tenuivirus. This indicates that the proteins encoded by EWSMV RNA2 are not mandatory for $N$. benthamiana infection. In RSV, NSvc2 protein encoded by RNA2 seems to be important for vector transmission (Lu et al. 2019). However, after 12 serial mechanical inoculations of RSV on $N$. benthamiana, there was no evidence for the loss of a fragment even if point mutations and limited deletions occurred in all RNAs, mostly in the noncoding regions ( $\mathrm{Lu}$ et al. 2018). In EWSMV, the proteins encoded by RNA2 may not be required for mechanical transmission of the virus and be lost by genetic drift or counter-selection. Vector transmissibility is often lost during serial mechanical passages of plant viruses (Legavre et al. 1996), suggesting that there may be a trade-off between infection efficiency and transmissibility (Froissart et al. 2010). In most cases, the loss of transmissibility is related to point mutation(s) or partial deletions in the viral components involved in transmission rather than in complete loss of a genomic component during prolonged multiplication in vegetatively propagated plants (Hernández et al. 1996; Legavre et al. 1996; Lindner et al. 2018). The transmissibility of EWSMV from $N$. benthamiana to either the same host or to wheat using the natural vector J. pellucida was not tested.

A low number of reads mapped to EWSMV RNA2 sequence, indicating possible low accumulation of this segment, was seen in HTS libraries respective to the field-collected wheat and spelt samples from Avinurme. Interestingly, lower rate of accumulation of RNA1 and RNA2 has been recently reported in rice seedlings microinjected with RSV propagated in vector insects, whereas the higher rate of accumulation was seen if RSV derived from the infected plants was used (Zhao et al. 2018). In the current study, it was also noticed that RNA2 of Hedesunda isolate sequenced from plant and planthopper samples showed slightly lower identity to each other than the other segments. As the tenuiviruses replicate both in their hosts and vectors, these finding may indicate the adaptive events related with shifting from one system to another.

Alignment-based sequence comparisons of the genome segments assembled for 15 EWSMV isolates from Estonia, Sweden, and Norway indicated that RNA1 was grouped in two subtypes whereas RNA2, RNA3, and RNA4 were grouped in three subtypes each. Grouping of the isolates varied dependent on the segment analyzed rather than on their geographic origin, indicating a reassortment of genome segments. Remarkably, the isolates collected from Avinurme had the highest variability in grouping, suggesting overall high natural diversity of EWSMV genome segments circulating around. 
However, more epidemiological surveys are needed to determine if this virus rediscovered by HTS technologies is indeed emerging or re-emerging in Northern Europe (Massart et al. 2017). RT-PCR protocol and genome sequences are now available for an unambiguous diagnostic and for molecular diversity studies that will help to understand better the genetic exchanges between viral populations, in order to develop efficient control methods.

The criteria demarcating species in the genus Tenuivirus are vector specificity (i.e., transmission by different species of vector), host range (i.e., different abilities to infect key plant species), different sizes, and/or numbers of RNA components (i.e., $<85 \%$ amino acid sequence identity between any corresponding gene products and $<60 \%$ nt sequence identity between corresponding noncoding intergenic regions). The genome of the novel virus described in current study consisting of four RNA segments showed less than $50 \%$ of sequence identity with other sequenced tenuiviruses both at nucleic acid and amino acid levels. Phylogenetic relationships revealed that it represents an evolutionarily distinct lineage in the genus Tenuivirus. It has a vector specificity (J. pellucida) characteristic of the previously reported but not sequenced tenuivirus EWSMV, different from any other known tenuiviruses. The host range data overlaps with that known for the tentative tenuivirus EWSMV. As described for EWSMV, the virus characterized here induces chlorotic spotting and streaking of leaves, general chlorosis, stunting and problems with head formation in infected cereal plants. It does not infect Alopecurus pratensis, Dactylis glomerata, Festuca rubra, Phleum pratense, or Poa pratensis as seen before for EWSMV. In contrast to earlier studies (Ikäheimio 1964; Vacke and Průša 1961), we also found L. multilorum nonsusceptible.

In conclusion, taxonomic information, host range data, symptomatology, and insect vector strongly suggest that we have most probably rediscovered the European wheat striate mosaic virus, and sequenced its genome more than 60 years after its first discovery.

\section{ACKNOWLEDGMENTS}

We acknowledge the collection of samples at Leirsund (Norway) by the farmer Harald Bøhnsdalen and the senior adviser Einar Strand.

\section{LITERATURE CITED}

Borucki, M., Chandler, L., Parker, B., Blair, C., and Beaty, B. 1999. Bunyavirus superinfection and segment reassortment in transovarially infected mosquitoes. J. Gen. Virol. 80:3173-3179.

Brčak, J. 1979. Leafhopper and planthopper vectors of plant disease agents in Central and Southern Europe. European wheat striate mosaic. Pages 97-117 in: Leafhopper Vectors and Plant Disease Agents. K.Maramorosch and K. F.Harris, eds. Elsevier Science and Technology.

Briese, T., Calisher, C. H., and Higgs, S. 2013. Viruses of the family Bunyaviridae: Are all available isolates reassortants? Virology 446: 207-216.

De Miranda, J., Hernandez, M., Hull, R., and Espinoza, A. M. 1994. Sequence analysis of rice hoja blanca virus RNA 3. J. Gen. Virol. 75:2127-2132.

Froissart, R., Doumayrou, J., Vuillaume, F., Alizon, S., and Michalakis, Y. 2010. The virulence-transmission trade-off in vector-borne plant viruses: A review of (non-)existing studies. Philos. Trans. R. Soc. B Biol. Sci. 365:1907-1918.

Gingery, R. E. 1987. The rice stripe virus group. Pages 297-329 in: The Filamentous Plant Viruses. R. G.Milne, ed. Plenum Press, New York.

Gingery, R. E., Nault, L. R., and Bradfute, O. E. 1981. Maize stripe virus: Characteristics of a member of a new virus class. Virology 112:99-108.

Gwiazdowski, R. A., Foottit, R. G., Maw, H. E. L., and Hebert, P. D. N. 2015. The Hemiptera (Insecta) of Canada constructing a reference library of DNA barcodes. PLoS One 10:e0125635.

Hebert, P. D. N., deWaard, J. R., Zakharov, E. V., Prosser, S. W. J., Sones, J. E., McKeown, J. T. A., Mantle, B., and La Salle, J. A. 2013. DNA 'barcode blitz': Rapid digitization and sequencing of a natural history collection. PLoS One 8:e68535.

Heikinheimio, O., and Raatikainen, M. 1976. Megadelphax sordidula (Stål) (Hom., Delphicidae) as a vector of Phleum green stripe virus. Ann. Agric. Fenn. 15:34-55.

Hemmes, H., Lakatos, L., Goldbach, R., Burgyan, J., and Prins, M. 2007. The NS3 protein of rice hoja blanca tenuivirus suppresses RNA silencing in plant and insect hosts by efficiently binding both siRNAs and miRNAs. RNA 13:1079-1089.

Hernández, C., Carette, J. E., Brown, D. J., and Bol, J. F. 1996. Serial passage of tobacco rattle virus under different selection conditions results in deletion of structural and nonstructural genes in RNA2. J. Virol. 70:4933-4940.

Huo, Y., Liu, W., Zhang, F., Chen, X., Li, L., Liu, Q., Zhou, Y., Wei, T., Fang, R., and Wang, X. 2014. Transovarial transmission of a plant virus is mediated by vitellogenin of its insect vector. PLoS Pathog. 10:e1003949.

Ikäheimio, K. 1960. Two cereal diseases in Finland. Maatal. Tiet. Aikak. (J. Sci. Agric. Soc. Finland) 32:62-70.

Ikäheimio, K. 1964. Host plants of wheat striate mosaic virus and oat steriledwarf virus. Ann. Agric. Fenn. 3:133-138.

Ikäheimio, K., and Raatikainen, M. 1961. Calligpona obscurella (Boh.), a new vector of the wheat striate mosaic and oat sterile-dwarf viruses. Maatal. Tiet. Aikak. (J. Sci. Agric. Soc. Finland) 33:146-152.

Jonson, M. G., Lian, S., Choi, H.-S., Lee, G.-S., Kim, C.-S., and Kim K.-H. 2011. Genetic reassortment of rice stripe virus RNA segments detected by RT-PCR restriction enzyme analysis-based method. Plant Pathol. J. 27: 148-155.

Kisimoto, R., and Watson, M. A. 1965. Abnormal development of embryos induced by inbreeding in Delphacodes pellucida Fabr. and Delphacodes dubia Kirschbaum (Araeopidae, Homoptera) vectors of European wheat striate mosaic virus. J. Invertebrate Pathol. 7:297-305.

Kumar, S., Stecher, G., Li, M., Knyaz, C., and Tamura, K. 2018. MEGAX: Molecular evolutionary genetics analysis across computing platforms. Mol. Biol. Evol. 35:1547-1549.

Lecoq, H., Wipf-Scheibel, C., Verdin, E., and Desbiez, C. 2019. Characterization of the first tenuivirus naturally infecting dicotyledonous plants. Arch. Virol. 164:297-301.

Legavre, T., Maia, I. G., Casse Delbart, F., Bernardi, F., and Robaglia, C. 1996. Switches in the mode of transmission select for or against a poorly aphidtransmissible strain of potato virus $\mathrm{Y}$ with reduced helper component and virus accumulation. J. Gen. Virol. 77:1343-1347.

Lindner, K., Hilbrich, I, and Koenig, R. 2018. Molecular characterization of variants of new 'rule-breaking' tobacco rattle virus RNA2 in potatoes. Virus Res. 244:270-275

Lindsten, K. 1961. A preliminary report of virus diseases of cereals in Sweden. Kungl. Lantbr. Högsk. Ann. 27:137-271.

Lindsten, K. 1974. Planthopper-transmitted virus diseases of cereals in Sweden. Mikrobiologija 11:55-66.

Lindsten, K. 1979. Planthopper vectors and plant disease agents in Fennoscandia. Pages 155-178 in: Leafhopper Vectors and Plant Disease Agents. K. Maramorosch and K. F. Harris, eds. Elsevier Science and Technology.

Liu, W., Gray, S., Huo, Y., Li, L., Wei, T., and Wang, X. 2015. Proteomic analysis of interaction between a plant virus and its vector insect reveals new functions of hemipteran cuticular protein. Mol. Cell. Proteomics 14: 2229-2242.

Lu, G., Li, S., Zhou, C., Qian, X., Xiang, Q., Yang, T., Wu, J., Zhou, X., Zhou, Y., Ding, X. S., and Tao, X. 2019. Tenuivirus utilizes its glycoprotein as a helper component to overcome insect midgut barriers for its circulative and propagative transmission. PLoS Pathog. 15:e1007655.

Lu, L., Wu, S., Jiang, J., Liang, J., Zhou, X., and Wu, J. 2018. Whole genome deep sequencing revealed host impact on population structure, variation and evolution of rice stripe virus. Virology 524:32-44

Massart, S., Candresse, T., Gil, J, Lacomme, C., Predajna, L., Ravnikar, M., Reynard, J.-S., Rumbou, A., Saldarelli, P., Škorić, D., Vainio, E. J., Valkonen, J. P. T., Vanderschuren, H., Varveri, C., and Wetzel, T. 2017. A framework for the evaluation of biosecurity, commercial, regulatory, and scientific impacts of plant viruses and viroids identified by NGS technologies. Front. Microbiol. 8:45.

Massart, S., Chiumenti, M., De Jonghe, K., Glover, R., Haegeman, A., Koloniuk, I., Komínek, P., Kreuze, J., Kutnjak, D., Lotos, L., Maclot, F., Maliogka, V., Maree, H. J., Olivier, T., Olmos, A., Pooggin, M. M., Reynard, J. S., Ruiz-García, A. B., Safarova, D., Schneeberger, P. H. H., Sela, N., Turco, S., Vainio, E. J., Varallyay, E., Verdin, E., Westenberg, M., Brostaux, Y., and Candresse, T. 2019. Virus detection by high-throughput sequencing of small RNAs: Large-scale performance testing of sequence analysis strategies. Phytopathology 109:488-497.

Massart, S., Olmos, A., Jijakli, H., and Candresse, T. 2014. Current impact and future directions of high throughput sequencing in plant virus diagnostics. Virus Res. 188:90-96.

Morales, F. J., and Jennings, P. R. 2010. Rice hoja blanca: A complex plant-virus-vector pathosystem. CAB Reviews 5:043.

Nuruzzaman, M., Manimekalai, R., Sharoni, A. M., Satoh, K., Kondoh, H., Ooka, H., and Kikuchi, S. 2010. Genome-wide analysis of NAC transcription factor family in rice. Gene 465:30-44.

Nuruzzaman, M., Sharoni, A. M., and Kikuchi, S. 2013. Roles of NAC transcription factors in the regulation of biotic and abiotic stress responses in plants. Front. Microbiol. 4:248. 
Nuruzzaman, M., Sharoni, A. M., Satoh, K., Karim, M. R., Harikrishna, J. A., Shimizu, T., Sasaya, T., Omura, T., Haque, M. A., Hasan, S. M., Ahmad, A., and Kikuchi, S. 2015. NAC transcription factor family genes are differentially expressed in rice during infections with rice dwarf virus, rice blackstreaked dwarf virus, rice grassy stunt virus, rice ragged stunt virus, and rice transitory yellowing virus. Front. Plant Sci. 6:676.

Oñate-Sánchez, L., and Vicente-Carbajosa, J. 2008. DNA-free RNA isolation protocols for Arabidopsis thaliana, including seeds and siliques. BMC Res. Notes 1:93.

Otuka, A. 2013. Migration of rice planthoppers and their vectored re-emerging and novel rice viruses in East Asia. Front. Microbiol. 4:309.

Pooggin, M. M. 2018. Small RNA-omics for plant virus identification, virome reconstruction, and antiviral defense characterization. Frontiers Microbiol. 9:2779.

Průša, V., and Vacke, J. 1960a. Transmission of wheat striate virus by the eggs of the vector, Callygpona pellucida Fabr. Biol. Plantarum 2:325-334.

Prǔša, V., and Vacke, J. 1960b. Wheat striate virus. Biol. Plantarum 2:276-286.

Raatikainen, M. 1967. Bionomics, enemies and population dynamics of Javesella pellucida (F.) (Hom., Delphacidae). Ann. Agric. Fenn. 6:7-147.

Schulz, M. H., Zebrino, D. R., Vingron, M., and Birney, E. 2012. Oases: Robust de novo RNA-seq assembly across the dynamic range of expression levels. Bioinformatics 28:1086-1092.

Seifers, D. L., Harvey, T. L., Martin, T. J., Haber, S., She, Y.-M., Ens, W., Standing, K. G., Salomon, R., and Gera, A. 2005. Association of a virus with wheat displaying yellow head disease symptoms in the Great Plains. Plant Dis. 89:888-895.

Serjeant, E. P. 1967. The transmission of European wheat striate mosaic virus by Javesella pellucida (Fabr.) injected with extracts of plants and planthoppers. Ann. Appl. Biol. 59:39-48.

Slykuis, J. T., and Watson, M. A. 1958. Striate mosaic of cereals in Europe and its transmission by Delpacodes pellucida (Fab.). Ann. Appl. Biol. 46:542-553.

Toriyama, S. 1995. Genus Tenuivirus. Pages 316-318 in: Virus taxonomy. Classification and nomenclature of viruses. Sixth report of the International
Committee on Taxonomy of Viruses. F. A.Murphy, C. M.Fauquet, D. H. L.Bishop, S. A.Ghabrial, A. W.Jarvis, G. P.Martelli, M. A.Mayo, and M. D.Summers, eds. Springer-Verlag, Vienna, Austria.

Toriyama, S., Kimishima, T., Takahashi, M., Shimizu, T., Minaka, N., and Akutsu, K. 1998. The complete nucleotide sequence of the rice grassy stunt virus genome and genomic comparisons with viruses of the genus Tenuivirus. J. Gen. Virol. 79:2051-2058.

Vacke, J., and Prưša, V. 1961. Host range of wheat striate virus. Biol. Plantarum 3:277-284.

Villamor, D. E. V., Ho, T., Al Rwahnih, M., Martin, R. R., and Tzanetakis, E. 2019. High throughput sequencing for plant virus detection and discovery. Phytopathology 109:716-725.

Wu, W., Zheng, L. M., Chen, H. Y., Jia, D.S., Li, F., and Wei, T. Y. 2014. Nonstructural protein NS4 of rice stripe virus plays a critical role in viral spread in the body of vector insects. PLoS One 9:e88636.

Xiong, R., Wu, J., Zhou, Y., and Zhou, X. 2009. Characterization and subcellular localization of an RNA silencing suppressor encoded by rice stripe tenuivirus. Virology 387:29-40.

Xiong, R. Y., Wu, J. X., Zhou, Y. J., and Zhou, X. P. 2008. Identification of a movement protein of rice stripe virus. J. Virol. 82:12304-12311.

Yao, M., Liu, X. F., Li, S., Xu, Y., Zhou, Y. J., Zhou, X. P., and Tao, X. 2014. Rice stripe tenuivirus NSvc2 glycoproteins targeted to the Golgi body by the N-terminal transmembrane domain and adjacent cytosolic 24 amino acids via the COP I- and COP II-dependent secretion pathway. J. Virol. 88: 3223-3234.

Zhao, W., Xu, Z., Zhang, X., Yang, M., Kang, L., Liu, R., and Cui, F. 2018. Genomic variations in the $3^{\prime}$-termini of rice stripe virus in the rotation between vector insect and host plant. New Phytol. 219: 1085-1096.

Zheng, L., Du, Z., Mao, Q., Wu, K., Wu, J., Wei, T., Wu, Z., and Xie, L. 2015. Rice stripe tenuivirus p2 may recruit or manipulate nucleolar functions through an interaction with fibrillarin to promote virus systemic movement. Mol. Plant Pathol. 16:921-930. 